\title{
KAJIAN PELAKSANAAN KEBIJAKAN PENDIDIKAN KARAKTER BERDASARKAN KURIKULUM 2013 DI SEKOLAH DASAR NEGERI KEC. LIMA KAUM KABUPATEN TANAH DATAR
}

\author{
Asnelly Ilyas \& Eliwatis \\ Jurusan Pendidikan Agama Islam, Fakultas Tarbiyah IAIN Batusangkar \\ Korespondensi: Jln. Sudirman No. 137 Kubu Rajo, Lima Kaum, Batusangkar \\ e-mail: asnelly58@gmail.com
}

\begin{abstract}
Decreasing attitude and/or moral values among students forced Indonesian government to be responsible to solve this problem through character building. Considering 'Undang-Undang RI No.17 Tahun 2005', this is a must for every school to over-come all problems that contribute to the decreasing attitute/ moral values of the students. Inhence, this research was done to know how was the implementation character education at schools. The design of the research was qualitative one. The researcher came to the class to observe the teaching and learning proseses (pre, whilst, and post activities) in order to get complete data. After analyzing the lesson plan and observation result of the teaching and learning proseses in the classroom, it could be known that there was the information of character building in the lesson plan (the learning objective, teaching steps and measurment). Then, the moral values were integrated in teaching materials by using cooperative learning, active learning, contexttual and expository strategy. In measuring the students' attitutel behaviour, the teacher faced difficulties in interpreting and scoring because there was no clear information of scoring students' character/ attitute.
\end{abstract}

Kata kunci: pendidikan, nilai-nilai karakter, pembelajaran, penilaian.

\section{PENDAHULUAN}

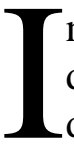

ndonesia dewasa ini Indonesia sedang dihadapkan pada persoalan dekadensi moral yang sangat serius. Pergeseran orientasi kepribadian yang mengarah pada berbagai prilaku amoral sudah sedemikian jelas dan tampak terjadi ditengah-tengah kehidupan masyarakat. Rasa malu, berdosa dan bersalah dari perbuatan buruk serta pelanggaran terhadap norma baik norma agama, hukum, dan sosial tidak lagi menjadi tuntunan dalam menciptakan kehidupan yang bertanggung jawab dalam memilhara nilai-nilai kemanusiaan.
Ratna Megawangi (2004: 3) mengatakan krisis multidemensi ini sebetulnya mengakar pada menurunya kualitas moral bangsa yang dicirikan membudayanya praktek KKN, konflik antar etnis/suku, agama, politisi, remaja, antar RT/RW dan sebagainya. Meningkatnya kriminalitas, menurunya etos kerja, budaya koropsi yang merupakan pelanggaran moral (ketidak jujuran, tidak bertanggung jawab, rendahnya disiplin, rendahnya komitmen pada nilainilai kebaikan, adalah penyebab utama, negara kita sulit untuk bangkit dari masalah krisis ini. 
Sebenarnya permasalahan di atas sudah diatasi dengan berbagai cara di antaranya adalah, pelatihan $\mathrm{P} 4$, pendidikan kepribadian di sekolah, pendidikan moral pancasila, menyusun dan mengadakan perbaikan perubahan kurikum, seperti kurikulum berbasis tujuan 1975-1984, Kurikulum Berbasis Kompetensi (KBK) tahun 2004 yang disempurnaka menjadi kurikulum KTSP (kurikulum tingkat satuan pendidikan) tahun 2006 dan yang terakhir kurikulum 2013. Namun pada saat ini persoalan tersebut masih belum teratasi, sehingga akhirnya pemerintah membuat kebijak-an lagi dengan istilah "pendidikan karakter "yang dituangkan dalam Undang-undang RI Nomor 17 Tahun 2007 tentang RPJPN 2005-2025) .."Tangguh, kompetitif, berakhlak mulia, bermoral, bertoleran, bergotong royong, patriotik, dinamis, berbudaya, dan berorientasi ipteks berdasarkan pancasila dan dijiwai oleh iman dan takwa kepada Tuhan Yang Maha Esa."dan Peraturan Pemerintah Nomor 19 Tahun 2005 Tentang Standar Nasional Pendidikan. Bab II (lingkup, Fungsi, dan Tujuan) Pasal 4, bahkan dalam tahun ajaran 2013-2014 pemerintah telah memberlakukan kurikulum 2013 yang pada hakikatnya bertujuan untuk tercapainya dan terwujudnya tujuan pendidikan karakter itu sendiri.

Berdasarkan uraian di atas maka peneliti tertarik melakukan penelitian dengan judul "Kajian Pelaksanaan Kebijakan Pendidikan Karakter Kurikulum 2013 di Sekolah Dasar Kec. Lima Kaum Kabupaten Tanah Datar Batungkar Sumbar".

\section{BATASAN DAN RUMUSAN MASALAH}

Berdasarkan uraian dari latar belakang masalah terdahulu, maka yang menjadi batasan masalah dalam penelitian ini adalah:1). Apakah guru sudah menuangkan nilai-nilai pendidikan karakter dalam persiapan pebelajarannya (RPP) berdasarkan kurikulum 2013 di SD kec.Lima Kaum Kabupaten Tanah Datar 2). Bagaimanakah guru mengimplementasikan nilai-nilai pendidikan karakter dalam pembelajaran dengan pendekatan saintifik dalam kurikulum 2013 di SD kec.Lima Kaum Kabupaten Tanah Datar 3). Bagaimanakah guru melakukan penilaian hasil belajar pendidikan karakter berdasarkan kurikulum 2013.di SD kec.Lima Kaum Kabupaten Tanah Datar. Adapun yang menjadi rumusan masalah dalam penelitian ini adalah bagaiamana pelaksanaan kebijakan pendidikan karakter dalam Kurikulum 2013 di Sekolah Dasar Kec.Lima Kaum Kabupaten Tanah Datar Batungkar Sumbar.

\section{TUJUAN DAN MANFAAT PENE- LITIAN}

Tujuan penelitian dengan judul kajian pelaksanaan kebijakan pendidikan karakter berdasarkan kurikulum 2013 di SD Kecamatan Lima Kaum Kab.Tanah Datar adalah untu menganalis: 1). Apakah guru sudah menuangkan nilai-nilai pendidikan karakter dalam persiapan pebelajarannya (dalam RPP) berdasarkan kurikulum 2013di SD kec.Lima Kaum Kabupaten Tanah Datar? 2.) Bagaimanakah guru mengimplementasikan nilainilai pendidikan karakter dalam pembelajaran dengan pendekatan saintifik dalam kurikulum 2013. 2013di SD kec.Lima Kaum Kabupaten Tanah Datar? 3). Bagaimanakah guru melakukan penilaian hasil belajar pendidikan karakter berdasarkan kurikulum 2013di SD kec.Lima Kaum Kabupaten Tanah Datar?. Sedangkan yang menjadi manfaat penelitian ini diharapkan: 1). Sebagai bahan pertimbangan atau acuan bagi pengambil kebijakan khusunya pihak dinas pendidikan kabupaten Tanah Datar tentang pelaksanaan pendidikan 
karakter berdasarkan kurikulum 2013 untuk masa yang akan datang. 2). Sebagai bahan renungan dan masukan bagi kepala sekolah dan guru SD di Kecamatan Lima Kaum Tanah Datar terhdap gambaran pelaksanaan pendidikan karakter berdasarkam kurikulum 2013.

\section{KAJIAN TEORI}

\section{Konsep Pendidikan Karakter}

\section{Hakikat Pendidikan Karakter}

Menurut Kamus Besar Bahasa Indonesia, karakter adalah sifat-sifat kejiwaan, akhlak, atau budi pekerti yang membedakan seseorang dari yang lain. (2011: 623). Sementara itu, istilah karakter yang dalam bahasa Inggris character, berasal dari istilah Yunani dari charassein yang berarti membuat tajam atau membuat dalam. (Jhon M.Echol: 2006). Karakter juga berarti mengukir, sifat utama ukiran adalah melekat kuat di atas benda yang diukir. Karena itu Wardani menyatakan bahwa karakter adalah ciri khass seseorang dan karakter tidak dapat dilepaskan dari konteks social budaya karena karakter terbentuk dalam lingkungan budaya tertentu.

Suyanto mendefinisikan karakter sebagai cara berpikir dan berprilaku yang menjadi ciri khas setiap individu untuk hidup dan bekerja sama, baik dalam lingkungan keluarga, masyarakat, bangsa dan negara. Karakter seseorang terbentuk karena kebiasaan yang dilakukan, sehiongga pada akhirnya menjadi sesuatu yang menempel pada kepribadian seseorang yang dilakukan secara berulang-ulang, yang pada awalnya disadari tetapi karena sudah sering dilakukan sehingga menjadi suatu pekerjaan yang menjadi kebiasaan.

Dengan demikian karakter mengacu pada serangkaian sikap (attitudes), perilaku (behaviors), motivasi (motivation), dan ketrampilan (skills). Thabroni, lebih jauh menegaskan bahwa, karakter merupakan nilai prilaku manusia yang berhubungan dengan Tuhan YME, diri sendiri, sesama manusia, lingkungan, dan kebangsaan yang terwujud dalam pikiran, sikap, perasaan, perkataan dan perbuatan berdasarkan norma-norma agama, hukum, tata karma, budaya dan adat istiadat.

Adapun pendidikan karakter adalah suatu proses pendidikan yang holistic yang menghubungkan dimensi moral dengan ranah social dalam kehidupan peserta didik sebagai fondasi bagi terbentuknya generasi yang berkualitas. Lebih rinci Agus Prasetyo mendefinisikan pendidikan karakter sebagai suatu sistem penanaman nilai-nilai karakter kepada peserta didik yang meliputi komponen pengetahuan, kesadaran atau kemauan, dan tindakan untuk melaksanakan nilai-nilai tersebut, baik terhadap Tuhan YME, diri sendiri, sesama, lingkungan, maupun kebangsaan sehingga menjadi manusia insan kamil. Zubaedi juga mengungkapkan hal yang senada bahwa pendidikan karakter adalah pendidikan budi pekerti plus, yang intinya merupakan program pengajaran yang bertujuan mengembangkan watak dan tabiat peserta didik dengan cara menghayati nilai-nilai yang menekankan ranah afektif tanpa meninggalkan ranah kognitif dan ranah skill.

Secara ringkas dapat dinyatakan bahwa pendidikan karakter adalah pendidikan melibatkan aspek pengetahuan (cognitive), perasaan (feeling) dan tindakan (action). Dengan demikian dapat dikatakan bahwa pendidikan karakter sebagai pendidikan yang menanamkan dan mengembangkan karakter-karakter luhur kepada peserta didik sehingga mereka memiliki karakter luhur tersebut, 
menerapkan dan mempraktekkan dalam kehidupannya sehari-hari.

\section{Tujuan dan Fungsi Pendidikan Karakter}

Pendidikan karakter pada intinya bertujuan membentuk bangsa yang tangguh, kompetitif, berakhlak mulia, bermoral, bertoleran, bergotong royong, berjiwa patriotik, berkembang dinamis, berorientasi ilmu pengetahuan dan teknologi yang semuanya dijiwai oleh iman dan takwa kepada Tuhan YME berdasarkan Pancasila. Pendidikan karakter bertujuan untuk meningkatkan mutu penyelenggaraan dan hasil pendidikan di sekolah yang mengarah pada pencapaian pembentukan karakter atau akhlak mulia peserta didik secara utuh, terpadu dan seimbang. Pendidikan karakter pada tingkatan institusi mengarah pada pembentukan budaya sekolah yaitu nilai-nilai yang melandasi perilaku, tradisi, kebiasaan keseharian dan simbol-simbol yang dipraktekkan oleh semua warga sekolah.

Dengan demikian, maka pendidikan karakter berfungsi untuk: pertama, mengembangkan potensi dasar agar berhati baik, berpikiran baik dan berprilaku baik; kedua, memperkuan dan membangun prilaku bangsa yang multicultural, dan ketiga, meningkatkan peradaban bangsa yang kompetitif dalam pergaulan dunia. Hal ini sesuai dengan fungsi Pendidikan Nasional yang tertuang dalam UU No.20 Tahun 2003 tentang Sisdiknas yang menyatakan bahwa pendidikan nasional berfungsi mengembangkan kemampuan dan membentuk watak serta peradaban bangsa yang bermartabat dalam rangka mencerdaskan kehidupan bangsa, bertujuan untuk mengembangkan potensi peserta didik agar menjadi manusia yang beriman dan bertaqwa kepada Tuhan YME, berakhlak mulia, sehat, berilmu, cakap, kreatif, mandiri dan menjadi warga negara yang demokratis serta bertanggung jawab.

\section{Nilai-Nilai Pembentuk Karakter}

Nilai-nilai karakter merupakan nilai-nilai yang akan ditanamkan kepada peserta didik yang bersumber dari agama, pancasila, budaya, tujuan pendidikan nasional dan UU RI No.17 tahun 2007. Berdasarkan sumber-sumber nilai karakter di atas maka lahirlah 18 nilai karakter yang harus dikembangkan dan dilaksanakan pada setiap satuan pendidikan.

Nilai-nilai karakter tersebut adalah: Religius, Jujur, toleransi, disiplin, kerja eras, kreatis, mandiri, deokratis, rasa ingin tahu, rasa kebangsaan, cinta tanah air, menghargai prestasi, cinta damai, komonikatif, gemar membaca, pedui lingkunga, peduli sosial dan tanggung jawab.

\section{Urgensi Pendidikan Karakter pada Sekolah Dasar}

Menurunnya kualitas moral dalam kehidupan manusia Indonesia dewasa ini, terutama di kalangan siswa, menuntut diselenggarakannya pendidikan karakter. Sekolah dituntut memainkan peran dan tanggung jawabnya untuk menanamkan dan mengembangkan nilainilai yang baik dan membantu para siswa membentuk dan membangun karakter mereka dengan nilai-nilai yang baik. Menurut Lickona, ada tujuh alasan mengapa pendidikan karakter itu harus disampaikan: a. Merupakan cara terbaik untuk menjamin siswa dapat memiliki kepribadian yang baik dalam kehidupannya, b. Merupakan cara untuk meningkatkan prestasi akademik, c. Sebagian siswa tidak dapat membentuk karakter yang kuat bagi dirinya di tempat lain, d. Mempersiapkan siswa untuk menghormati pihak atau orang lain dan dapat hidup dalam masyarakat yang beragam, e. Berangkat dari akar masalah yang berkaitan dengan problem moral, 
social seperti ketidaksopanan, ketidakjujuran, kekerasan, pelanggaran moral dan sebagainya, f. Merupakan persiapan terbaik untuk menyonsong prilaku di tempat kerja nantinya, g. Mengajarkan nilai-nilai budaya merupakan bagian dari kerja peradaban.

M.Furqon Hidayatullah dalam Jamal Ma'mur Asmani (2011: 85) mengklasifikasikan pendidikan karakter dalam beberapa tahap yaitu: a. Tahap penanaman adab (usia 5-6 tahun). Adab atau tata karma bisa dilihat dari tata cara seseorang dalam bertutur sapa, berinteraksi, bersikap dan bersosialisasi. Saat inilah fase paling penting untuk menanamkan nilai kejujuran, pendidikan keimanan (tauhid), serta menghormati orang tua, teman sebaya dan orang-orang yang lebih tua. b. Tahap penanaman tanggung jawab (usia 7-8 tahun) Tanggung jawab merupakan perwujudan dari niat dan tekad untuk melakukan tugas yang diemban. c. Tahap penanaman kepedulian (usia 9-10 tahun). Kepedulian adalah empati kepada orang lain yang diwujudkan dalam bentuk memberikan pertolongan sesuai dengan kemampuan. Anak diajari menolong temannya yang sedang dilanda musibah, misalnya mengunjungi teman yang sedang sakit, mengajari teman tentang materi yang belum dipahami, berbagi ketika sedang makan dan sebagainya. Kepedulian ini sangat penting dalam rangka menumbuhkan rasa persaudaraan dan kekeluargaan, serta menjauhkan diri dari sifat sombong, egois dan individual. d. Tahap penanaman kemandirian (usia 11-12 tahun), sikap mandiri merupakan pola pikir dan sikap yang lahir dari semangat yang tinggi dalam memandang diri sendiri. Beberapa nilai dalam kemandirian antara lain tidak menggantung pada diri orang lain, percaya kepada kemampuan diri sendiri dan tidak merugikan orang lain. Menumbuhkan sikap kemandirian dalam diri peserta didik dapat dilakukan dengan melaktih mereka bekerja dan menghargai waktu. e. Tahap penanaman pentingnya bermasyarakat (usia 13 tahun ke atas). Bermasyarakat adalah simbol kesediaan seseorang untuk bersosialisasi dan bersinergi dengan orang lain. Dalam konteks pendidikan karakter, pola hidup bermasyarakat membutuhkan banyak tips sukses, di antaranya mengajari anak bergaul dan berteman dengan anak-anak yang mempunyai karakter yang baik seperti disiplin, menghargai waktu, kreatif, moralis dan mencintai pengetahuan.

\section{Kurikulum 2013 Berbasis Kompetensi dan Karakter}

Wina Sanjaya (2006: 68) menjelaskan kompetensi sebagai tujuan, dimaksudkan dengan kompetensi tersebut adalah perpaduan dari pengetahuan, keterampilan, nilai dan sikap yang direfleksikan dalam kebiasaan berpikir dan bertindak. Seorang yang telah memiliki kompetensi dalam bidag tertentu bukan hanya mengetahui, tetapi juga dapat memahami dan menghayati bidang tertentu yang tertermin dalam pola perilaku sehari-hari.

Jadi kompetensi dipahami merupakan penguasaan terhadap suatu tugas, ketrampilan, sikap dan apresiasi yang diperlukan untuk menunjang keberhasilan. Hal tersebut menunjukkan bahwa komptetensi mencakup tugas, keterampilan, sikap dan apresiasi yanh harus dimiliki peserta didik untuk dapat melaksanakan tugas-tugas pembelajaran sesuai dengan jenis pekerjaan tertentu. Dengan demikian terdapat hubungan (link) antara tugas-tugas yang dipelajari peserta didik di sekolah dengan kemampuan yang diperlukan oleh dunia kerja. 
Lebih lanjut Wina Sanjaya, mengatakan dalam sebuah kompetensi terdapat beberapa aspek yaitu: pengetahuan (knowledge), pemahaman (understanding), kemahiran (skill), nilai (value), sikap (attitude) dan minat (interest)

Dari enam aspek kompetensi di atas dapat dipahami bahwa kompetensi sebagai tujuan dalam kurikulum bertujuan untuk mengembangkan pengetahuan, pemahaman, kecakapan, nilai, sikap dan minat siswa agar mereka dapat melakukan sesuatu dalam bentuk kemahiran dan rasa tanggung jawab. Dengan perkataan lain bahwa tujuan yang dicapai dalam kompetensi ini bukan hanya sekedar pemahaman akan materi pelajaran, akan tetapi bagaimana pemahaman dan penguasaan materi dapat mempengaruhi cara bertindak dan berperilaku dalam kehidupan sehari-hari.

\section{Perencanaan Pembelajaran Berka- rakter}

Rencana Pelaksanaan Pembelajaran (RPP)

RPP merupakan perkiraan guru utuuk melakukan tindakan yang akan dilakukan dalam kegiatan pembelajaran di kelas. Berdasarkan Peraturan Nomor 19 tahun 2005 dinyatakan bahwa perencanaan proses pembelajaran memuat sekurang-kurangnya tujuan pembelajaran, materi ajar, metode pengajaran, sumber belajar dan penilaian hasil belajar. RPP adalah disain pembelajaran yang didisain sendiri oleh pendidik sesuai dengan bidang studinya dan wewenang sepenuhnya diserahkan pada pendidik tersebut dengan beracukan Prota, Prosem serta Silabus Pembelajaran.

Agar RPP memberi petunjuk pada guru dalam menciptakan pembelajaran yang berwawasan pada pengembangan karakter, maka RPP tersebut diadaptasi seperti adaptasi terhadap silabus. Adaptasi dapat dilakukan pada kegiatan pem- belajaran yang mengembangkan karakter, indikator pencapaian kompetensi yang mencerminkan nilai-nilai karakter dan juga teknik penilaian yang juga mengukur perkembangan karakter siswa.

\section{Proses Pelaksanaan Pembelajaran Berkarakter}

\section{Kegiatan Pendahuluan}

Pendahuluan merupakan kegiatan awal dalam suatu pertemuan pembelajaran yang ditujukan untuk membangkitkan motivasi dan memfokuskan perhatian peserta didik untuk berpartisipasi aktif dalam proses pembelajaran. Lebih konkrit,berdasarkan Standar Proses, maka kegiatan pendahuluan, tugas guru adalah (a). Menyiapkan peserta didik secara psikis dan fisik untuk mengikuti proses pembelajaran. (b). Mengajukan pertanyaan-pertanyaan yang mengaitkan pengetahuan sebelumnya dengan materi yang akan dipelajari. (c) Menjelaskan tujuan pembelajaran atau kompetensi dasar yang akan dicapai. (e). Menyampaikan cakupan materi dan penjelasan uraian kegiatan sesuai silabus

\section{Kegiatan Inti}

Kegiatan inti merupakan proses pembelajaran untuk mencapai KD. Kegiatan pembelajaran dilakukan secara interaktif, inspiratif, menyenangkan, menantang, memotivasi peserta didik untuk berpartisipasi aktif, serta memberikan ruang yang cukup bagi prakarsa, kreativitas, dan kemandirian sesuai dengan bakat, minat, dan perkembangan fisik serta psikologis peserta didik. Kegiatan ini dilakukan secara sistematis dan sistemik melalui proses eksplorasi, elaborasi, dan konfirmasi. Berdasarkan Peraturan Mentri Pendidikan Nasional Nomor 41 tahun 2007, kegiatan inti pembelajaran terbagi atas tiga tahap yaitu eksplorasi, elaborasi dan konfirmasi. 


\section{Kegiatan Penutup}

Penutup merupakan kegiatan yang dilakukan untuk mengakhiri aktivitas pembelajaran yang dapat dilakukan dalam bentuk rangkuman atau kesimpulan, penilaian dan refleksi, umpan balik, dan tindak lanjut.

\section{Penilaian Pendidikan Karakter dalam Kurikulum 2013}

Penilaian merupakan rangkaian kegiatan untuk memperoleh, menganalisis, dan menafsirkan data tentang proses dan hasil belajar peserta didik yang dilakukan secara sistematis dan berkesinambungan, sehingga menjadi informasi yang bermakna dalam pengambilan keputusan.

Penilaian dilakukan secara terus menerus, setiap saat guru berada di kelas atau di sekolah. Model anecdotal record (catatan yang dibuat guru ketika melihat adanya perilaku yang berkenaan dengan nilai yang dikembangkan) selalu dapat digunakan guru.

Dari hasil pengamatan, catatan anekdotal, tugas, laporan, dan sebagainya, guru dapat memberikan kesimpulan atau pertimbangan tentang pencapaian suatu indikator atau bahkan suatu nilai. Penilaian tersebut dapat dinyatakan dalam betuk kualitatif sbb: BT (belum terlihat), MT (mulai terlihat), MB (mulai berkembang), dan MK (membudaya).

\section{METODOLOGI PENELITIAN}

\section{Jenis Penelitian.}

Penelitian ini merupakan penelitian kebijakan, menurut Sudarwan Danim dengan mengunakan pemikiran Majchrzak, mengemukan bahwa penelitian kebijakan merupaka penelitian yang masuk dalam kelompok penelitian terapan, dan dimaksudkan sebagai usaha untuk menkaji masalah-masalah sosial yang fondamental dalam kaitannya untuk mengkkreasi tindakan pragmatis dalam rangka memperbaiki dan membenahi masalah sosial. (Riant Nugroho, 2014: 101)

Berdasarkan pengertian penilitian kebijakan tersebut, maka penelitian ini akan mencoba mengkaji dan menganalisa secara mendalam tentang pelaksanaan kebijakan pendidikan karakter yang sudah dilakukan di SD kecamatan Lima Kaum Kabupate Tanah Datar, yang bertujuan untuk memperoleh gambaran pelaksanaan kebijakan pendidikan karakter di SD Kec.lima Kaum Kabupaten Tanah Datar. Metode Penelitian yang digunakan adalah metode kualitatif, yaitu dengan ciri menggunakan setting alami (lapangan), bersifat diskriptif, menekankan pada proses (pelaksanaan), menggunakan pendekatan induktif. Metode kualitatif dipergunakan dengan cara melakukan pengumpulan data primer secara langsung dilapangan, dengan cara mewancarai seluruh pelaku utama dalam pelaksanaan kebijakan secara mendalam, dilakukan observasi langsung terhadap objek penelitian.

\section{Sumber Data dan Sampel Penelitian}

Sumber data atau informan dari penelitian ini adalah pendidik (guru) kelas, kepala sekolah, tenaga kependidikan, yang berada di kec.Lima kaum Kab.Tanah Datar. Sedangkan yang menjadi area penelitan SD yang ada di Kecamatan Lima Kaum Kabupaten Tanah Datar berjumlah 28 SDN. Berhubung karena keterbatasn waktu, biaya, dan tenaga, maka yang dijadikan sampel dalam penelitian ini adalah 5 buah SD dengan pertimbangan ke lima SD tersebut ada yang berada dekat ke ibu kota kecamatan, jauh dan pinggir kota kecamatan. 


\section{Teknik Pengumpulan Data}

Teknik pengumpulan data dalam penelitian ini dengan menggunakan

a. Observasi, yaitu mengamati secara langsung tentang pelaksanaan pendidikan karakter oleh pendidik dan tenaga kependidikan serta oleh kepala sekolah. Selain observasi dapat diamati secara langsung peneliti dapat melihat, mengamati sendiri dan mencatat perilaku dan kejadian pada keadaan yang sebenarnya,

b. Wawancara, wawancara ini dilakukan kepada sumber data untuk menyempurnakan hal-hal yang tidak terungkap/tercofer ketika meakukan observasi.

c. Dekumentasi, dekumentasi yang dimaksudkan disini adalah dekumentasi berupa Rencana Program Pembelajaran (RPP) yang dibuat oleh guru sebelum pembelajaran berlangsung.

\section{Teknik Analisis Data}

Analisa data yang diguakan dalam penelitian ini adalah kualitatif maksudnya adalah menguraikan dan menjelaskan data yang diperoleh melalui observasi, wawancara, dan dekumen. Uji keabsahan data dilakukan dengan cara: trianggulasi. Analisis data menggunakan model interaktif Miles dan Huberman melalui empat tahapan, yang meliputi: pengumpulan data, reduksi data, penyajian data, dan pengambilan kesimpulan

\section{HASIL PENELITIAN}

Sesuai dengan batasan dari penelitian ini mencakup 3 aspek, pertama: adalah

\section{Nilai-nilai Pendidikan Karakter dalam Rencana Pelaksanaan Pem- belajaran (RPP)}

Untuk mendapat data tentang apakah guru sudah menuangkan nilai- nilai pendidikan karakter dalam persiapan pelaksanaan pembelajaran, peneliti melakukan wawancara dengan beberapa orang guru. Pertanyaan pertama yang peneliti ajukan kepadanya adalah mengenai kurikulum yang dipakai dalam pembelajaran, apakah kurikulum KTSP atau kurikulum 2013?. Berdasarkan informasi dari informan diketahui bahwa ada empat sekolah dasar negeri yang ada di kecamatan Lima Kaum ini yang memakai kurikulum 2013 yaitu SDN 01, SDN 06, SDN 11 dan SDN 26, dan selebihnya menggunakan kurikulum KTSP.

Pertanyaan kedua adalah apakah guru sudah menuangkan nilai-nilai karakter dalam RPP yang mereka susun?". Berdasarkan wawancara tersebut diketahui bahwa pada umumnya guru-guru sudah menuangkan nilai-nilai karakter dalam perumusan Rencana Pelaksanaan Pembelajaran (RPP)nya. Hal ini berdasarkan ungkapan informan/responden: "Di sekolah kami para guru-guru sudah mencantumkan nilai-nilai karakter dalam persiapan pembelajarannya".

Berdasarkan study/analisa dokumentasi terhadap RPP yang disusun guru-guru tersebut baik yang berdasarkan kurikulum 2013 maupun RPP yang dibuat berdasarkan kurikulum KTSP, memang sudah menuangkan nilai-nilai karakter dalam perumuasan RPP tersebut,baik dalam merumuskan tujuan pembelajaran, langkah pembelajaran maupun pada penilaiannya.Kalau dianalisis lebih jauh terdapat perbedaan guru-guru dalam menuangkan nilai nilai karakter tersebut pada rencana pelaksanaan pembelajarannya (RPP). Adapun perbedaannya adalah:

1) Pada kurikulum 2013, nilai-nilai karakter terdapat pada komponen perumusan kompetensi inti yaitu pada KI 1, KI 2, KI 3 dan KI 4, seperti nilai karakter cinta Tuhan dan alam semesta beserta isinya pada KI 1, sedangkan karakter sikap disiplin, 
jujur tanggung jawab, peduli, santun dan lainnya tertuang pada KI 2, sedangkan karakter rasa ingin tahu dituangkan pada KI 3, sementara itu pada KI 4 tercermin nilai karakter tanggung jawab, percaya diri dan karakter lainnya. Sementara pada kurikulum KTSP, nilai-nilai karakter tersebut dituangkan secara konkrit dan tersendiri setelah komponen tujuan pembelajaran dengan membuat satu komponen khusus yaitu komponen karakter yang diharapkan.

2) Komponen langkah-langkah pembelajaran. Pada Kurikulum 2013 ini, pendekatan pembelajaran yang digunakan adalah pendekatan saintifik dengan lima aspek kegiatan yaitu mengamati, menanya, eksperimen, asosiasi dan komunikasi, dengan demikian nilai-nilai karakter, seharusnya dituangkan oleh guru pada setiap aspek pembelajaran dengan pendekatan saintifik tersebut. Misalnya pada aspek mengamati terkandung nilai karakter rasa ingin tahu dan karakter ketelitian terhadap materi yang diamati, adapun pada aspek bertanya terkandung nilai karakter berani, rasa ingin tahu dan karakter gemar membaca. Pada aspek eksperimen terkandung nilainilai karakter seperti karakter kerja keras ,karakter rasa ingin tahu karakter teliti, karakter komunikatif, karakter gemar membaca dan karakter tanggung jawab. Adapun pada aspek asosiasi terkandung nilai nilai karakter seperti karakter kreatif, karakter tanggung jawab dan karakter mandiri. Sementara pada aspek komunikasi terkandung nilai nilai karakter di antaranya karakter mandiri, karakter berani, karakter jujur, karakter komunikatif, karakter tanggung jawab. Namun dalam langkahlangkah pembelajaran pada Rencana
Pelaksanaan Pembelajaran (RPP) berdasarkan kurikulum 2013 ini tidak dituangkan oleh guru tentang nilai-nilai karakter tersebut secara konkrit, hal ini berdampak pada kesulitan guru dalam melakukan penilaian hasil belajar afektif anak. Sedangkan RPP yang dibuat oleh guru berdasarkan kurikulum KTSP, mencantumkan nilai-nilai karakter yang akan dikembangkan pada siswa secara konkrit.

3) Komponen penilaian hasil belajar. Pada penilaian karakter/ sikap, baik berdasarkan kurikulum 2013 maupun kurikulum yang berdasarkan KTSP, dilakukan dengan cara observasi (pengamatan) dengan menggunakan lembar obervasi yang dibuat guru dengan mencantumkan kriteria dan bobot penilaian sikap/karakter yaitu pertama BT (Belum Terlihat) dengan skor 1 yaitu apabila peserta didik belum memperlihatkan tanda-tanda awal prilaku yang dinyatakan dalam indikator, kedua, MT (Mulai Terlihat) dengan skor 2 yaitu apabila peserta didik sudah mulai memperlihatkan adanya tanda-tanda awal dari prilaku yang dinyatakan dalam indikator tetapi belum konsisten, ketiga MB (Mulai Berkembang) dengan skor 3 yaitu apabila peserta didik sudah memperlihatkan berbagai tanda prilaku yang dinyatakan dalam indikator dan mulai konsisten, keempat MK (Membudaya) dengan skor 4 yaitu apabila peserta didik terus menerus memperlihatkan perilaku yang dinyatakan dalam indikator secara konsisten. Adapun karakter yang dinilai sesuai dengan sikap atau karakter yang terkandung pada materi ajar dan penilaian proses sewaktu pembelajaran berlangsung. 


\section{Pelaksanaan Pendidikan Karakter dalam Proses Pembelajaran}

Berdasarkan temuan lapangan diketahui bahwa pelaksanaan pendidikan karakter dalam proses pembelajaran di kelas dilakukan guru dengan menggunakan beberapa strategi, di antaranya:

1) Berdasarkan hasil wawancara peneliti dengan guru dan kepala sekolah, tepatnya dalam hal ini dengan guru mata pelajaran IPA SDN 26, informan menjelaskan pendidikan karakter dilaksanakan dalam pembelajaran secara integrasi pada materi atau bahan ajar yang ada pada waktu itu seperti misalnya materi Lingkungan Hidup dalam mata pelajaran IPA, metode yang digunakan guru dalam pembelajaran adalah metode kooperatif atau belajar kelompok. Guru membagi siswa beberapa kelompok seperti ada kelompok satu, dua, tiga dan empat, masingmasing kelompok terdiri dari 4-5 orang siswa yang membahas materi yang berbeda. Informan tersebut juga menjelaskan ketika masing-masing kelompok berdiskusi membahas tema yang sudah ditentukan maka muncullah nilai-nilai karakter dalam kegiatan diskusi seperti nilai ingin tahu dengan membaca materi melalui buku-buku teks yang mereka miliki, nilai karakter yang lain seperti bekerjasama, berani mengeluarkan pendapat, menghargai pendapat teman, tanggung jawab, sikap bersaing atau berkompetesi antar kelompok.

2) Nilai-nilai karakter juga dapat dimunculkan dengan menggunakan strategi pembelajaran aktif lainnya, seperti strategi membangun tim, nilai karakter yang terdapat di dalammnya adalah kerja sama, kepedulian sosial, komunikatif, tanggung jawab dan toleransi. Namun berdasarkan pengamatan di lapangan, diketahui bahwa tidak semua karakter yang sudah ditetapkan Mendikbud yaitu $18 \mathrm{ka}-$ rakter, dapat dimunculkan dalam satu strategi pembelajaran aktif, karena itu, seharusnya guru-guru menggunakan staregi pembelajaran secara kombinasi beberapa strategi dan bervariasi.

3) Nilai karakter yang dimunculkan dengan menggunakan strategi pembelajaran kontekstual yaitu dengan cara menekankan pada proses keterlibatan peserta didik untuk menemukan materi yang dipelajari dan menghubungkannya dengan situasi nyata, sehingga dapat digunakan dalam kehidupan sehari hari. Konsekwensi dari penggunaan strategi ini adalah bahwa peserta didik tidak sekedar mendengar dan mencatat pelajaran dari guru melainkan harus mengalaminya sendiri secara langsung. Dengan demikian setidaknya terdapat 6 karakter yang muncul dengan menggunakan strategi ini yaitu karakter kerja keras, karakter toleransi, karakter demokrasi, karakter mandiri, karakter peduli sosial dan peduli lingkungan.

4) Nilai karakter yang dimunculkan guru dengan menggunakan strategi pembelajaran ekspositori, dimana strategi ini masih sangat banyak digunakan oleh guru dalam proses pembelajaran. Dengan menggunakan strategi ini, maka guru dapat memunculkan karakter rasa ingin tahu, dan sedikit nilai karakter komunikatif. Dengan demikian, jika guru cendrung sering menggunakan strategi ekspositori saja, maka hanya sebagian kecil saja nilai karakter siswa yang dapat dikembangkan.

Lebih jauh, jika ditinjau berdasarkan nilai-nilai karakter yang akan dikembangkan,maka dalam proses pembelajaran dilakukan guru dengan cara berikut ini: 
a) Karakter religius: Karakter religius dalam pembelajaran dapat dirangsang dengan cara mengajak siswa berdoa sebelum dan sesudah pembelajaran, dan melatih siswa untuk melaksanakan ibadah.

b) Karakter jujur: Karakter jujur dibentuk, misalnya dengan melarang siswa menyontek dan mengembalikan barang temuan yang hilang.

c) Karakter toleransi: Untuk membentuk karakter toleransi pada peserta didik dilakukan guru dengan melatih dan menempatkan peserta didik untuk bekerja dengan kelompok yang berbeda tanpa membedakan status sosial dan ras.

d) Karakter disiplin: untuk membentuk karakter disiplin, maka peserta didik dibiasakan hadir tepat waktu, mengumpulkan PR tepat waktu, dan mematuhi aturan sekolah.

e) Karakter kerja keras: untuk memunculkan karakter kerja keras pada peserta didik, dilakukan guru dengan menciptakan suasana kompetesi yang sehat serta menciptakan suasana belajar yang memacu daya tahan kerja dengan memajang slogan slogan yang memacu semangat untuk giat bekerja dan belajar.

f) Karakter kreatif: dilakukan guru dengan pemberian tugas-tugas yang menantang sehingga muncul karyakarya baru dari siswa.

g) Karakter mandiri: dilakukan guru dengan menciptakan suasana kelas yang memberikan kesematan kepada peserta didik untuk bekerja secara mandiri.

h) Karakter demokrasi: dilaksanakan guru dengan cara mengambil keputusan: kelas secara bersama melalui musyawarh dan mufakat seperti dalam pemilihan pengurus kelas dilakukan secara terbuka. i) Karakter rasa ingin tahu: karakter ini dibentuk dengan cara menciptakan suasana kelas yang mengundang rasa ingin tahu

j) Karakter semangat kebangsaan dan cinta tanah air: karakter ini dibina guru dengan cara mengajak siswa memperingati momen- momen nasional seperti hari kemerdekaan Indonesia, hari pahlawan dan lain lain.

k) Karakter menghargai prestasi: karakter ini di bentuk guru dengan cara menciptakan suasan pembelajarkan yang memotivasi peserta didik untuk meraih prestasi.

1) Karakter bersahabat komunikatif: dilakukan guru dengan cara mengatur kelas yang memudahkan terjadinya interaksi antar peserta didik, dengan mendengarkan keluhan dari peserta didik serta berkomunikasi intensif dengan peserta didik.

m) Karakter cinta damai: dilakukan guru dengan menciptakan suasana kelas yang damai, membaskan prilaku peserta didik yang anti kekerasan serta menciptakan keakraban yang penuh kasih sayang di kelas.

n) Karakter gemar membaca: dilakukan guru dengan cara merangsang peserta didik untuk membaca bukubuku refrensi.

o) Karakter peduli sosial, dilakukan dengan cara beremphaty kepada sesama teman kelas dengan melakukan aksi sosial dan membangun kerukunan peserta didik

p) Karakter peduli lingkungan: karakter ini dibentuk guru dengan cara memelihara lingkungan kelas, menyediakan tempat sampah dan membiasakan hidup hemat energi.

q) Karakter tanggung jawab: untuk membentuk karakter tanggung jawab pada peserta didik dilakukan guru dengan cara melaksanakan tugas 
piket secara teratur dan berperan aktif dalam kegiatan sekolah serta mengajukan usul pemecahan masalah.

Sementara itu, berdasarkan wawancara dengan Kepala Sekolah diketahui bahwa pelaksanaan pendidikan karakter dalam pembelajaran dengan pendekatan saintifik yang digunakan guru sudah memunculkan perubahan karakter/sikap pada siswa, antara lain mulai terlihat keakraban antara guru dan siswa ketika di dalam kelas dan luar kelas, dalam berbicara /berkomunikasi siswa dengan guru sudah menggunakan bahasa yang santun,di samping itu siswa juga memiliki motivasi yang tinggi untuk belajar yang terbukti dengan banyaknya siswa yang membaca buku waktu istirahat di dalam kelas, tidak mau keluar kelas untuk main.

\section{Pelaksanaan Penilaian Hasil Belajar Pendidikan Karakter Berdasarkan Kurikulum 2013}

Dalam hal penilaian hasil belajar pendidikan karakter, berdasarkan wawancara dengan responden dan berdasarkan analisis terhadap dokumen penilaian yang dibuat oleh guru maka ditemukan beberapa hal berikut:

1) Dari segi format penilaian: Secara umum dapat diketahui bahwa format penilaian pendidikan karakter, dibuat dan disusun oleh masing-masing guru secara individual sehingga memunculkan format penilaian karakter yang berbeda beda, sebagaimana terlampir pada lampiran 4.

2) Dari segi aspek karakter yang dinilai terdapat perbedaan guru dalam memberikan penilaian. Perbedaan tersebut adalah penilaian nilai karakter yang dilakukan oleh guru kelas dan guru bidang studi, dimana guru kelas menetapkan nilai karakter yang sama yang dinilai untuk satu semester pada semua bidang studi selain bidang studi agama dan bidang studi olah raga (misalnya karakter kedisiplinan, kebersihan, sopan santun, hubungan sosial, dan kejujuran), sedangkan guru bidang studi melakukan penilaian karakter dengan menentukan nilai karakter yang akan dinilai berdasarkan materi pokok pelajaran. Sebagaimana terdapat pada lampiran 5.

3) Dari segi teknik penilaian hasil belajar pendidikan karakter, semua responden menggunakan teknik observasi/pengamatan dengan menggunakan lembar observasi yang dibuat oleh guru dan penilaian karakter tersebut dilakukan pada saat pembelajaran berlangsung. Hal ini mengakibatkan kegiatan guru dalam menyampaikan materi ajar menjadi terganggu karena guru disibukkan dengan mengamati dan memberikan penilaian karakter, dimana guru diharuskan mengisi lembar obeservasi pada saat pembelajaran berlangsung.

4) Dari segi penentuan skor dan pemberian nilai akhir. Walaupun sudah ada kriteria penentuan skor terhadap karakter yang dinilai dengan kriteria BT, MT, MB dan MK dengan skor $1,2,3$, dan 4 , namun para responden, masih mengalami kesulitan dalam memahami kriteria yang ada karena belum adanya indikator yang dapat terukur, kesulitan yang dialami responden diperparah dengan pemahaman responden terhadap prilaku yang muncul dari peserta didik untuk diposisikan pada pilihan kriteria yang ada. Kesulitan resonden dalam penentuan skor tersebut berdampak pada kesulitan responden dalam menentukan nilai akhir pendidikan karakter peserta didik, sehingga ketepatan nilai karakter yang diperoleh oleh peserta didik tersebut menjadi kurang valid.

5) Dari segi proses/ tahapan yang dilakukan guru pada setiap aspek karakter yang dinilai, umumnya res- 
ponden mengalami kerumitan dalam proses penghitungan nilai karakter harian dan proses rekapitulasi nilai akhir pendidikan karakter peserta didik di akhir semester ditambah lagi dengan kebingungan responden dalam mencantumkan hasil belajar karakter peserta didik pada raport peserta didik, baik hasil belajar karakter dalam bentuk huruf maupun narasinya.

\section{PENUTUP}

Dalam pembuatan Rencana Pelaksanaan Pembelajaran (RPP), nilai-nilai karakter yang disusun oleh guru tercermin pada komponen tujuan pembelajaran, komponen langkah/skenario pembelajaran dan pada komponen penilaian. Namun dalam teknisnya antara kurikulum 2013 dengan kurikulum KTSP terdapat sedikit perbedaan yaitu nilai-nilai karakter pada kurikulum 2013, terkandung pada rumusan kompetensi inti (KI) dan pada kegiatan inti dalam proses pembelajaran dengan mengunakan pendekatan saintifik, serta pada komponen penilaian. Adapun dalam kurikulum KTSP, nilai-nilai karakter dirumuskan dalam komponen tersendiri setelah komponen tujuan pembelajaran dan pada kegiatan inti (proses pembelajaran) dicantumkan secara eksplisit nilai karakter yang diharapkan.

Dalam pelaksanaan pembelajaran, nilai-nilai karakter tersebut diintegrasikan melalui materi dan metode/strategi pembelajaran yang digunakan guru, di antaranya dengan menggunakan strategi kooperatif learning, strategi active learning, kontekstual learning dan ekspository.

Dalam pelaksanaan penilaian hasil belajar pendidikan karakter, guru menggunakan teknik obervasi dengan instrumen lembar obeservasi yang dibuat sendiri oleh guru berdasarkan kriteria dan skore penilaian yang sudah ditetapkan. Namun dalam penginterpretasian dan proses penetapan skore nilai karakter tersebut, guru mengalami kesulitan disebabkan prosedur pemberian skore yang rumit dan indikator-indikator nilai karakter yang ada belum terukur secara jelas.

\section{DAFTAR RUJUKAN}

Abdul Majid. 2014. Pembelajaran Tematik Terpadu. Bandung: PT. Remaja Rosda Karya.

Badruddin. 2014. Manajemen Peserta Didik. Jakarta: Indeks.

Daryanto. 2013. Pendidikan Karakter di Sekolah. Jogyakarta: Gava Media.

Damiyati Zuchdi. Dkk. 2013. Model Pendidikan Karakter. Jogyakarta.

Depdiknas. Undang-undang nomor 20 tahun 2003 tentang Sistem Pendidikan Nasional.Jakarta: Depdiknas. 2003
2005. Undang-undang nomor 14 tahun 2005 tentang Guru dan Dosen. Jakarta: Depdiknas.

2005. Peraturan Pemerintah nomor 19 tahun 2005 tentang Standar Nasional Pendidikan. Jakarta: Depdiknas.

Husamah. 2013. Disain Pembelajaran Berbasis Pencapaian Kompetensi. Jakarta: Prestasi Pustaka.

Jamal Ma'mus Asmani. 2011. Panduan Internalisasi Pendidikan Karakter di Sekolah. Jogayakarta: Diva Press. 
Kunandar. 2009. Guru Profesional: Implementasi Kurikulum Tingkat satuan Pendidikan (KTSP) dan Sukses dalam Sertifikasi Guru. Jakarta: Rajawali.

Masnur Muslich. 2011. Pendidikan Karakter Menjawab Tantangan Krisis Multi Dimensional. Jakarta: Bumi Aksara.

Mulyasa. 2007. Standar Kompetensi dan Sertifikasi Guru. Bndung: PT Remaja Rosda Karya.

Mulyasa. 2014. Pengembangan dan Implementasi Kurikulum 2013. Bandung: Remaja Rosda Karya.

Nurla Isna Aunillah, 2011. Panduan Menerapkan Pendidikan Karakter di Sekolah, Jogyakarta, Laksana,
Syamsul Kurniawan. 2013. Pendidikan Karakter. Jakarta: Ruzz Media.

Suharsimi Arkunto. 2005. Manajemen Penelitian. Jakarta: Rineka Cipta.

Sugiyono. 2007. Metode Penelitian Pendidikan Pendekatan Kuantitatif, Kualitatif, dan $R \& D$. Bandung: Penerbit Alphabeta.

Riant Nugroho, 2014. Metode Penelitian Kebijakan, Yoyakarta, Pustaka Pelajar.

Wina Sanjaya. 2005. Pembelajaran dalam Implementasi Kurikulum Berbasis Kompetensi. Jakarta: Kencana. 